\title{
The Effect of Transarterial Y-90 Microsphere Treatment on Biochemical Parameters in Liver Tumors
}

\author{
Karaciğer Tümörlerinde Transarteriyel Y-90 Mikroküre Tedavisinin Biyokimyasal \\ Parametreler Üzerine Etkisi
}

(D) Burçak Yılmaz, (D) Cihan Gündoğan

İstanbul Training and Research Hospital, Clinic of Nuclear Medicine, İstanbul, Turkey

\begin{abstract}
Introduction: The aim of this study was to evaluate the effect of yttrium-90 (Y-90) microsphere transarterial radioembolization (TARE) treatment on early and late biochemical parameters and to determine the appropriate and effective follow-up schedule in the patients and to determine the biochemical parameters to be considered.
\end{abstract}

Methods: A total of 106 patients with histopathologically verified primary or metastatic unresectable liver tumors that were treated with TARE at a single institution between 20162018 were retrospectively scanned from database. Of these patients, 27 patients (18 male and 9 female patients; mean age: $61.5 \pm 10.5$ years, range: $40-77$ years) were included in the study. It was investigated whether there was a significant difference between the biochemical parameters just before the treatment, on the $10^{\text {th }}$ day and 3 months after the treatment.

Results: Statistically significant difference was observed only between pre-treatment albumin (albumin 1) and $10^{\text {th }}$ day albumin (albumin 2), and between pre-treatment albumin (albumin 1) and $3^{\text {rd }}$ month albumin (albumin 3) levels $(p<0.05)$. There was no statistically significant difference between other biochemical parameters ( $p>0.05)$.

Conclusion: Albumin value was the most sensitive biochemical parameter in TARE treatment with Y-90 microsphere. It is of great importance that albumin value is frequently followed carefully in these patients.

Keywords: Y-90 microsphere, radio-embolization, side effect, liver

\section{öZ}

Amaç: Yitriyum-90 (Y-90) mikroküre ile transarteriyel radyoembolizasyon (TARE) tedavisinin erken ve geç biyokimyasal parametreler üzerine etkisinin araștırılarak tedavi edilen hastalarda uygun ve etkili takip planının yapılması ve özellikle dikkat edilmesi gereken biyokimyasal parametrelerin belirlenmesi amaçlanmıștır.

Yöntemler: Yerel veri tabanınından tek merkezde 2016-2018 yılları arasında primer veya metastatik inoperabl karaciğer tümörü histopatolojik olarak kanıtlanmıș toplam 106 hastaya TARE tedavisi uygulandığı saptandı. Bu hastaların 27 tanesinin

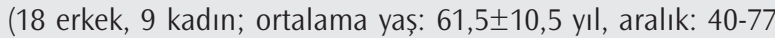
yıl) tedavi öncesi, erken ve geç tedavi sonrası tüm biyokimyasal parametrelerine ulaşılarak çalışmaya dahil edildi. Tedaviden hemen önce, tedavi sonrası 10. gün ve 3. ay biyokimyasal parametreler arasında anlamlı farklılık olup olmadığı araștırıldı.

Bulgular: İstatistiksel anlamlı farklılık sadece tedavi öncesi albümin (albümin 1) ile tedavi sonrası 10. gün takip albümin (albümin 2) değerleri ile tedavi öncesi albümin (albümin 1) ile tedavi sonrası 3. ay takip albümin (albümin 3) değerleri arasında saptandı $(p<0,05)$. Bakılan diğer biyokimyasal parametreler arasında ise istatistiksel herhangi bir anlamlı fark saptanamadı ( $p>0,05)$.

Sonuç: Y-90 mikroküre ile TARE tedavisinde en hassas biyokimyasal parametrenin albümin değeri olduğu saptanmıștır. Tedavi uygulanan hastalarda albümin değeri takiplerinin sıklıkla ve dikkatle takibi büyük önem tașımaktadır.

Anahtar Kelimeler: Y-90 mikrosfer, radio-embolizasyon, yan etki, karaciğer
Address for Correspondence/Yazıssma Adresi: Burçak Yılmaz MD, İstanbul Training and Research Hospital, Clinic of Nuclear Medicine, ìstanbul, Turkey

Phone: +90 2124596000 E-mail: drburcak@gmail.com ORCID ID: orcid.org/0000-0002-6979-0990

Cite this article as/Atıf: : Yılmaz B, Gündoğan C. The Effect of Transarterial Y-90 Microsphere Treatment on Biochemical Parameters in Liver Tumors. İstanbul Med J 2019; 20(5): 436-40.
Received/Gelis Tarihi: 17.07.2019 Accepted/Kabul Tarihi: 22.08.2019

(C) Copyright 2019 by the Istanbul Training and Research Hospital/istanbul Medical Journal published by Galenos Publishing House.

(C) Telif Hakkı 2019 istanbul Ĕgitim ve Araștırma Hastanesi/Istanbul Tıp Dergisi, Galenos Yayınevi tarafından basılmıștır. 


\section{Introduction}

Liver cancer, including primary hepatocellular carcinoma and intrahepatic cholangiocarcinoma (comprising $10-15 \%$ of cases) as well as other rare types, is the sixth most commonly diagnosed cancer and the fourth leading cause of cancer-related death worldwide in 2018, with about 841.000 new cases and 782.000 deaths annually (1). In addition, liver is a frequent site of metastasis for many common malignancies such as breast and colon (2-4). The prognosis of unresectable liver cancer is poor (5). Treatment options include chemotherapy, transarterial chemoembolization, regional radiotherapy, radiofrequency ablation, transarterial radioembolization (TARE) and transplantation (5).

In recent years, TARE with yttrium-90 (Y-90) microspheres has become a safe treatment option for unresectable primary and metastatic liver malignancies (6-9). It may also be preferred as a bridge prior to resection, radiofrequency ablation and liver transplantation (7). TARE may be helpful in the management of advanced liver malignancies (1013). Its palliative role through tumor necrosis and delaying progression has also been shown (6).

TARE is an internal, local, highly selective radiation therapy that has minor embolization effects (14). This treatment modality has less side effects and complications when compared to other local and systemic therapies of liver malignancies with the help of different arterial access to tumor tissue $(6,14)$. In order to decide TARE treatment, complete blood count and biochemical tests including liver and renal function (albumin, total bilirubin, aspartate amino transferase, alanine amino transferase, blood urea nitrogen and creatinine) should be analyzed. Biochemical tests, clinical status of patients and possible side effects should be checked regularly after treatment (14). The most frequent side effects of the treatment occur immediately after treatment and they usually do not need further treatment. On the other hand, rare serious side effects and complications can be observed mostly 3 months following TARE $(15,16)$.

The aim of this study was to evaluate the early and late effects of TARE treatment on biochemical parameters and to determine the appropriate follow-up schedule.

\section{Methods}

\section{Patient Population and Data Collection}

The study protocol was approved by the İstanbul Training and Research Hospital Local Ethics Committee as a retrospective study (decision no: 1584, date: 21.12.2018). A total of 106 patients with histopathologically verified primary or metastatic unresectable liver tumors that were treated with TARE at a single institution for 2 years were identified from our database. Medical records of the patients were scanned to collect clinicopathological and biochemical results. Patients with previous TARE treatment, patients with previous abnormal biochemical tests and patients with a follow-up of less than 6 months were excluded from the study. Twenty-seven patients (18 male, 9 female; mean age: $61.5 \pm 10.5$ years, range: $40-77$ years) with available pre-treatment and 3 months follow-up biochemical tests were included in the current study. The study population included 10 patients with primary hepatic malignancy (hepatocellular carcinoma) and 17 patients with hepatic metastasis (12 colorectal cancers, two neuroendocrine tumors, one ovarian carcinoma, one breast cancer and one malignant melanoma).

Neutrophil count (normal range: $\left.34-71.1 \times 10^{\wedge} 9 / \mathrm{L}\right)$, C-reactive protein (CRP) (normal range: $0-5 \mathrm{mg} / \mathrm{L}$ ), aspartate aminotransferase (AST) (normal range: 0-35 IU/L), alanine aminotransferase (ALT) (normal range: 0-35 IU/L), albumin (normal range: $3.5-5.2 \mathrm{~g} / \mathrm{dL}$ ), total bilirubin (normal range: $0.3-1.2 \mathrm{mg} / \mathrm{dL}$ ), direct bilirubin (normal range: $0-0.2$ $\mathrm{mg} / \mathrm{dL}$ ), tumor markers such as alpha-fetoprotein (normal range: 0-9 $\mu \mathrm{g} / \mathrm{L}$ ), carcinoembryonic antigen (normal range: 0-3 U/mL), Ca-15-3 (normal range: $0-31.3 \mathrm{U} / \mathrm{mL}$ ) and $\mathrm{Ca}-125$ (normal range: $0-35 \mathrm{U} / \mathrm{mL}$ ) were measured before the day of treatment. On the $10^{\text {th }}$ day of followup, neutrophil count, CRP, AST, ALT, albumin, total and direct bilirubin levels were noted. At the $3^{\text {rd }}$ month of the treatment, all parameters evaluated during pretreatment tests were re-recorded.Istanbul Training and Research Hospital, Clinical Research Ethics Committee (decision no: 1584, date: 21.12.2018).

\section{Technical Information}

Before treatment, baseline F-18 fluorodeoxyglucose positron emission tomography/computed tomography (PET/CT) imaging (Figure 1) and magnetic resonance imaging were performed. Also, all patients underwent liver angiography with technetium-99m (Tc-99m)-labeled micro-aggregated albumin (MAA) scintigraphy to determine aberrant vasculature and also to calculate the percentage of pulmonary shunting (17). The total volume of the liver and the tumor area were determined using Tc-99m MAA single PET/CT scan (4). Whole liver dose, tumor dose and healthy injected liver dose were all calculated by using the medical internal radiation dose formula $(8,18)$. For both Tc-99m MAA scintigraphy and also for TARE treatment, the femoral artery route was preferred to reach the right and/or left hepatic artery. The patients were discharged home on the following day of the treatment and were seen every 10 days for one month and then regularly every month to monitor side

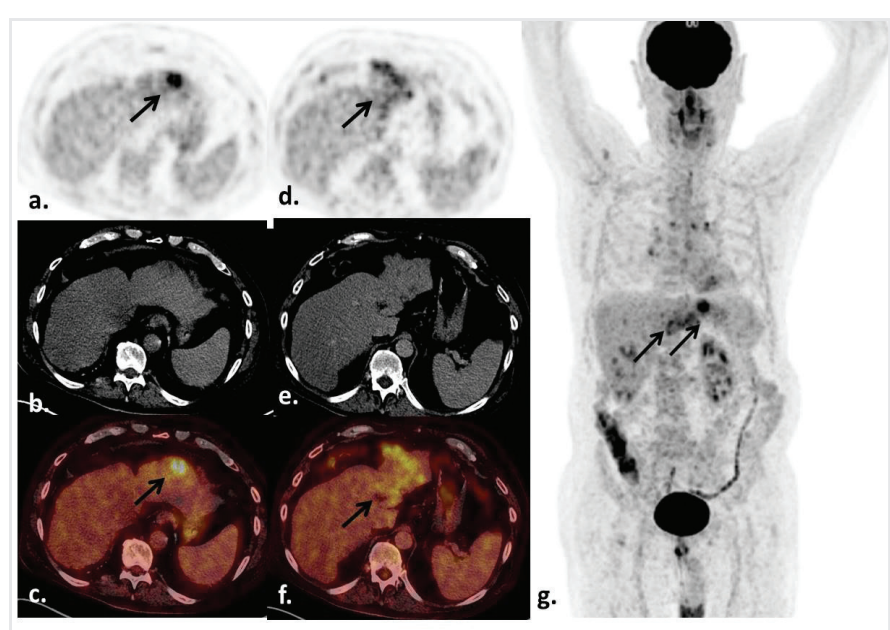

Figure 1. Pretreatment F-18 FDG PET/CT images of a 57-year-old male patient with hepatocellular carcinoma showed high FDG uptake in the left lobe of the liver extending along the portal vein without any distant metastasis: Axial PET (a), CT (b), fusion (c) and MIP images (d) (arrows)

FDG: fluorodeoxyglucose, PET: positron emission tomography, CT: computed tomography, MIP: maximum intensity projection 
effects, complications, disease burden, and also for further treatment requirements (4).

\section{Statistical Analysis}

All statistical analyses were performed using SPSS software (Version 20.0; SPSS Inc., New York, NY) with a value of $p<0.05$ considered to be statistically significant. Paired t-test was used to compare pretreatment and $10^{\text {th }}$ day early post-treatment and also $3^{\text {rd }}$ month post-treatment biochemical parameters.

\section{Results}

Between August 2016 and September 2018, 106 TARE procedures were performed in our institution. A total of 27 TARE procedures in 27

Table 1. Descriptive analysis of biochemical parameters before and early or late after treatment

\begin{tabular}{|c|c|c|}
\hline Variable & Mean \pm SD & Range \\
\hline \multicolumn{3}{|l|}{ Pre-treatment parameters } \\
\hline Neutrophil-1 (n=27) & $4.6 \pm 2.1$ & $1.2-10.5$ \\
\hline CRP-1 $(n=27)$ & $4.1 \pm 4.9$ & $0.2-14.2$ \\
\hline ALT-1 $(n=27)$ & $32.5 \pm 26.9$ & $11-124$ \\
\hline AST-1 $(n=27)$ & $44.5 \pm 32.2$ & $14-166$ \\
\hline Albumin-1 $(n=27)$ & $4.0 \pm 0.5$ & $3.3-5.9$ \\
\hline Total bilirubin-1 $(n=27)$ & $0.9 \pm 0.45$ & $0.35-1.89$ \\
\hline Direct bilirubin-1 $(n=27)$ & $0.2 \pm 0.2$ & $0.05-1.01$ \\
\hline AFP-1 $(n=10)$ & $7315.9 \pm 17225.5$ & $1.3-54000$ \\
\hline CEA-1 $(n=12)$ & $26.2 \pm 23.6$ & $3.6-72.4$ \\
\hline Ca-15-3.1 ( $n=1)$ & 76.2 & - \\
\hline Ca-125.1 ( $n=2)$ & $44.3 \pm 22.8$ & $26.0-59.0$ \\
\hline \multicolumn{3}{|c|}{ Post-treatment (Early) Parameters ( $10^{\text {th }}$ day) } \\
\hline Neutrophil-2 & $4.3 \pm 1.7$ & $1.7-8.7$ \\
\hline CRP-2 & $9.7 \pm 12.9$ & $0.7-49.2$ \\
\hline ALT-2 & $41.5 \pm 29.2$ & $9-116$ \\
\hline AST-2 & $58.1 \pm 33.1$ & $17-141$ \\
\hline Albumin-2 & $3.7 \pm 0.5$ & 2.3-4.4 \\
\hline Total bilirubin-2 & $1.4 \pm 2.7$ & $0.4-14.4$ \\
\hline Direct bilirubin-2 & $0.5 \pm 1.5$ & $0.03-7.6$ \\
\hline \multicolumn{3}{|c|}{ Post-treatment (late) parameters ( $3^{\text {rd }}$ month) } \\
\hline Neutrophil-3 & $5.04 \pm 3.1$ & $2.5-16.3$ \\
\hline CRP-3 & $10.8 \pm 17.9$ & $0.5-67.2$ \\
\hline ALT-3 & $39.0 \pm 33.9$ & $11-171$ \\
\hline AST-3 & $55.0 \pm 55.8$ & $28.0-300.0$ \\
\hline Albumin-3 & $3.5 \pm 0.6$ & $2.5-4.8$ \\
\hline Total bilirubin-3 & $1.8 \pm 3.2$ & $0.5-17.05$ \\
\hline Direct bilirubin-3 & $0.7 \pm 1.8$ & $0.04-9.35$ \\
\hline AFP-3 & $16938.9 \pm 44706.9$ & $2.06-142760.0$ \\
\hline CEA-3 & $25.7 \pm 38.6$ & $1.4-96.1$ \\
\hline Ca-15-3.3 & 118.1 & - \\
\hline Ca-125.1 (n=2) & $111.5 \pm 117.2$ & 28.6-194.4 \\
\hline
\end{tabular}

SD: standard deviation, CRP: C-reactive protein, ALT: alanine aminotransferase, AST: aspartate aminotransferase, AFP: alpha-fetoprotein, CEA: carcinoembryonic antigen patients, who met the inclusion criteria, were included in the current study. Table 1 lists the descriptive analysis of the biochemical tests just before the treatment, on the $10^{\text {th }}$ day of follow-up and at 3 months of the follow up.

The patient population was heterogeneous with different previous treatment histories including chemotherapy. The majority of patients received treatment to the right lobe $(n=22 ; 81.5 \%)$ and $18.5 \%$ received treatment only to the left lobe $(n=5)$. The most common side effect following treatment was post-embolization syndrome with fatigue, nausea, low-grade fever, and right upper quadrant pain. No grade 2 or 3 adverse events were detected during follow-up visits in the study population. None of the patients were treated with a total bilirubin level greater than $2 \mathrm{mg} / \mathrm{dL}$ or albumin level $<3 \mathrm{~g} / \mathrm{dL}$.

Statistical significance was observed only between pre-treatment albumin (albumin 1) and $10^{\text {th }}$ day albumin (albumin 2), and between pre-treatment albumin (albumin 1) and $3^{\text {rd }}$ month albumin (albumin 3) levels $(p<0.05)$. There was no statistically significant difference between the other biochemical parameters $(p>0.05)$ (Table 2).

\section{Discussion}

Our institutional experience of TARE with Y-90 microsphere has shown that it is a relatively safe local treatment option for unresectable intrahepatic malignancies in the scope of biochemical parameters, although albumin levels changed significantly early after the treatment and in the late follow up.

TARE can selectively provide very high radiation exposure to tumor tissue with fewer side effects. Previous studies have shown that this therapy is an effective and safe option for unresectable liver malignancies such

\begin{tabular}{l|l|}
\hline $\begin{array}{l}\text { Table 2. Statistical analysis of biochemical parameters before } \\
\text { treatment, early or late after treatment }\end{array}$ \\
\hline Biochemical parameters & $\mathbf{p}$ \\
\hline ALT-1/ALT-2 & 0.174 \\
\hline ALT-1/ALT-3 & 0.402 \\
\hline AST-1/AST-2 & 0.059 \\
\hline AST-1/AST-3 & 0.145 \\
\hline Neutrophil-1/Neutrophil-2 & 0.528 \\
\hline Neutrophil-1/Neutrophil-3 & 0.540 \\
\hline CRP-1/CRP-2 & 0.081 \\
\hline CRP-1/CRP-3 & 0.122 \\
\hline Total Bilirubin-1/Total bilirubin-2 & 0.299 \\
\hline Total Bilirubin-1/Total bilirubin-3 & 0.162 \\
\hline Direct Bilirubin-1/Direct bilirubin-2 & 0.278 \\
\hline Direct Bilirubin-1/Direct bilirubin-3 & 0.170 \\
\hline Albumin-1/Albumin-2 & 0.001 \\
\hline Albumin-1/Albumin-3 & 0.001 \\
\hline AFP-1/AFP-3 & 0.320 \\
\hline CEA-1/CEA-3 & 0.875 \\
\hline p value<0.05=statistically significant & \\
\hline AFP: alpha-fetoprotein, CEA: carcinoembryonic antigen & \\
\hline
\end{tabular}


as hepatocellular carcinoma and liver metastases from colorectal and breast cancer, neuroendocrine tumors, melanoma, pancreatic, renal and lung cancer $(6,10,14,19)$.

Y-90 is a high-energy beta emitter that is used to label microspheres. Radiolabeled microspheres cannot get through venous capillaries due to their larger diameter than the end arterial capillary bed. So, Y-90 labeled microspheres are trapped in the tumor bed and high radiation doses can be achieved in the tumor tissue, causing irreversible cell damage in the epithelial, stromal, and endothelial cells of the area (14). Endothelial cells were suggested to be the main and first target of internal radiation therapy. Endothelial cells of tumors are damaged and cell death is observed afterwards $(20,21)$. In addition, malfunction and transient failure of the liver may be observed after treatment, which may lead to insufficient production of some proteins (22). These mechanisms may explain why albumin levels in this study were significantly decreased during very early and late follow-up.

Common side effects of treatment are nausea, vomiting, mild abdominal pain and fever with a reported incidence of $20-70 \%$, and may be associated with systemic reaction to endothelial damage $(14,23)$. Vascular dissection/occlusions, pseudo-aneurysms, liver abscess formation, biliomas, cholecystitis, gastritis, duodenitis, pleural effusions and perihepatic fluid collections are some of the mild to serious complications after TARE (6). Transaminase enzymes may increase transiently in the first 4-6 weeks of treatment and may last up to 2-3 months (14). It has been shown that liver toxicity is up to $96 \%$ in terms of transaminase levels in patients treated with the whole liver approach (24). In another phase 2 study, altered bilirubin levels were reported at 3 months in $13.5 \%$ of patients (25). In contrast, no clinically apparent hepatic toxicity was observed in another large cohort study (26). In the current study, similar to the results of the last study, we could not demonstrate significant fluctuation of transaminases or bilirubin levels either in the early or late follow-up of patients.

Radiation-induced liver damage was described many years ago in the scope of external beam radiotherapy that is related with centrilobular vein damage (27). In this syndrome, ascites without jaundice, elevated alkaline phosphatase and less frequently increased liver transaminases are observed (28). On the other hand, radioembolization-induced liver damage, which is a typical liver toxicity syndrome specifically associated with radioembolization, has recently been described (29). Severe abdominal pain, ascites, jaundice, bilirubin elevation, variable elevation of gamma gamma glutamyl transferase, and alkaline phosphatase without significant increase in transaminase enzymes and decreasing blood albumin levels usually at the $3^{\text {rd }}$ month of treatment are the components of the syndrome $(14,28)$. This can also promote our study data that albumin is the critical parameter that must be checked regularly. In a recently published study, it was shown that significant decline in overall survival was observed as serum albumin, and hence hepatic synthetic function, even with the majority of patients having a normal total bilirubin. They also concluded that the median overall survival of patients with normal serum albumin was greater and that patients with an albumin below $3 \mathrm{~g} / \mathrm{dL}$ might not derive a significant clinical benefit from treatment with Y-90 TARE when albumin fell below
$3 \mathrm{~g} / \mathrm{dL}$ (4). Similarly, an albumin level $>3 \mathrm{~g} / \mathrm{dL}$ has been previously reported as a predictor of survival in a group of patients with colorectal histology treated with Y-90 TARE (30).

The primary purpose of this study was to identify the effect of treatment on early and late follow-up biochemical parameters that could be used to predict safety and efficacy.

\section{Study Limitations}

Our study population was heterogeneous in terms of demographics and histology, which is one of the main limitations along with retrospective design. Additionally, follow-up duration was not long enough to give information about relationship between survival and biochemical parameters.

\section{Conclusion}

Our experience with Y-90 TARE has shown that it is a relatively safe treatment option in the scope of biochemical parameters for properly screened patients with intrahepatic malignancies. Our data suggests that the critical biochemical parameter is albumin, which should be checked regularly before, early and late after treatment.

Ethics Committee Approval: İstanbul Training and Research Hospital, Clinical Research Ethics Committee (decision no: 1584, date: 21.12.2018).

Informed Consent: Informed consent forms were obtained.

Peer-review: Internally peer-reviewed.

Author Contributions: Concept - B.Y., C.G.; Design - B.Y., C.G.; Supervision - B.Y.; Resources - B.Y., C.G.; Materials - B.Y., C.G.; Data Collection and/ or Processing - B.Y., C.G.; Analysis and/or Interpretation - B.Y.; Literature Search - B.Y.; Writing Manuscript - B.Y.; Critical Review - B.Y., C.G.

Conflict of Interest: No conflict of interest was declared by the authors.

Financial Disclosure: The authors declared that this study received no financial support.

\section{References}

1. Bray F, Ferlay J, Soerjomataram I, Siegel RL, Torre LA, Jemal A. Global cancer statistics 2018: GLOBOCAN estimates of incidence and mortality worldwide for 36 cancers in 185 countries. CA Cancer J Clin 2018; 68: 394-424.

2. Simmonds PC, Primrose JN, Colquitt JL, Garden OJ, Poston GJ, Rees M. Surgical resection of hepatic metastases from colorectal cancer: a systematic review of published studies. Br J Cancer 2006; 94: 982-99.

3. Mayo SC, Pawlik TM. Current management of colorectal hepatic metastasis. Expert Rev Gastroenterol Hepatol 2009; 3: 131-44.

4. Orwat KP, Beckham TH, Cooper SL, Ashenafi MS, Anderson MB, Guimaraes M, et al. Pretreatment albumin may aid in patient selection for intrahepatic Y-90 microsphere transarterial radioembolization (TARE) for malignancies of the liver. J Gastrointest Oncol 2017; 8: 1072-8.

5. Özgür 0 , Gündüz Ş, Erkılıç $M$, Bozcuk HŞ, Sindel HT. Yttrium-90 radioembolization for the treatment of unresectable liver cancer: Results of a single center. Dicle Medical Journal 2014; 41: 10-6.

6. Venkatanarasimha N, Gogna A, Tong KTA, Damodharan K, Chow PKH, Lo RHG, et al. Radioembolisation of hepatocellular carcinoma: a primer. Clin Radiol 2017; 72: 1002-13. 
7. Rhee S, Kim S, Cho J, Park J, Eo JS, Park S, et al. Semi-quantitative analysis of post-transarterial radioembolization (90)Y microsphere positron emission tomography combined with computed tomography (PET/CT) images in advanced liver malignancy: comparison with $(99 \mathrm{~m}) \mathrm{Tc}$ macroaggregated albumin (MAA) single photon emission computed tomography (SPECT). Nucl Med Mol Imaging 2016; 50: 63-9.

8. Topcuoglu OM, Alan Selcuk N, Sarikaya B, Toklu T. Safety of transarterial radioembolization with Yttrium-90 glass microspheres without cystic artery occlusion. Radiol Med 2019; 124: 575-80.

9. Meiers C, Taylor A, Geller B, Toskich B. Safety and initial efficacy of radiation segmentectomy for the treatment of hepatic metastases. J Gastrointest Oncol 2018; 9: 311-5.

10. Cosimelli M, Golfieri R, Cagol PP, Carpanese L, Sciuto R, Maini CL, et al. Multi-centre phase II clinical trial of yttrium-90 resin microspheres alone in unresectable, chemotherapy refractory colorectal liver metastases. Br J Cancer 2010; 103: 324-31.

11. Hendlisz A, Van Den Eynde M, Peeters M, Maleux G, Lambert B, Vannoote J, et al. Phase III trial comparing protracted intravenous fluorouracil infusion alone or with yttrium-90 resin microspheres radioembolization for liverlimited metastatic colorectal cancer refractory to standard chemotherapy. J Clin Oncol 2010; 28: 3687-94.

12. Gulec SA, Pennington K, Wheeler J, Barot TC, Suthar RR, Hall M, et al. Yttrium-90 microsphere-selective internal radiation therapy with chemotherapy (chemoSIRT) for colorectal cancer liver metastases. Am J Clin Oncol 2013; 36: 455-60.

13. Ozkan ZG, Poyanli A, Ucar A, Kuyumcu S, Akyuz F, Keskin S, et al. Favorable survival time provided with radioembolization in hepatocellular carcinoma patients with and without portal vein thrombosis. Cancer Biother Radiopharm 2015; 30: 132-8.

14. Bozkurt MF, Salanci BV, Uğur Ö. Intra-arterial radionuclide therapies for liver tumors. Semin Nucl Med 2016; 46: 324-39.

15. Kennedy AS, McNeillie P, Dezarn WA, Nutting C, Sangro B, Wertman D, et al. Treatment parameters and outcome in 680 treatments of internal radiation with resin 90Y-microspheres for unresectable hepatic tumors. Int J Radiat Oncol Biol Phys 2009; 74: 1494-500.

16. Sangro B, Bilbao JI, Boan J, Martinez-Cuesta A, Benito A, Rodriguez J, et al. Radioembolization using 90Y-resin microspheres for patients with advanced hepatocellular carcinoma. Int J Radiat Oncol Biol Phys 2006; 66: 792-800.

17. Bermo M, Matesan MC, Itani M, Behnia F, Vesselle HJ. Hepatopulmonary shunting on Tc99m-MAA liver mapping: correlation with dynamic cross- sectional imaging and description of different shunting patterns. Abdom Radiol (NY) 2018; 43: 3001-8.

18. https://ctep.cancer.gov/protocoldevelopment/electronic_applications/docs/ CTCAE_v5_Quick_Reference_8.5x11.pdf

19. Soydal C, Keskin O, Kucuk ON, Ozkan E, Bilgic S, Idilman R, et al. Prognostic factors for prediction of survival of hepatocellular cancer patients after selective internal radiation therapy. Ann Nucl Med 2015; 29: 426-30.

20. Paris F, Fuks Z, Kang A, Capodieci P, Juan G, Ehleiter D, et al. Endothelial apoptosis as the primary lesion initiating intestinal radiation damage in mice. Science 2001: 293; 293-7.

21. Folkman J, Camphausen K. Cancer. What does radiotherapy do to endothelial cells? Science 2001; 293: 227-8.

22. Riaz A, Lewandowski RJ, Kulik LM, Mulcahy MF, Sato KT, Ryu RK, et al. Complications following radioembolization with yttrium-90 microspheres: A comprehensive literature review. J Vasc Interv Radiol 2009; 20: 1121-30.

23. Riaz A, Awais R, Salem R. Side effects of yttrium-90 radioembolization. Front Oncol 2014; 4: 198.

24. Dancey JE, Shepherd FA, Paul K, SnidermanKW, Houle S, Gabrys], et al. Treatment of non respectable hepatocellular carcinoma with intrahepatic 90 yttrium microspheres. J Nucl Med 2000; 41: 1673-81.

25. Mazzaferro V, Sposito C, Bhoori S, Romito R, Chiesa C, Morosi C, et al. Yttrium (90) radioembolization for intermediate-advanced hepatocarcinoma: A phase II study. Hepatology 2013; 57: 1826-37.

26. Hilgard P, Hamami M, Fouly AE, Scherag A, Müller S, Ertle J, et al. Radioembolization with yttrium-90 glass microspheres in hepatocellular carcinoma: European experience on safety and long-term survival. Hepatology 2010; 52: 1741-9.

27. Reed GB Jr, Cox AJ Jr. The human liver after radiation injury. A form of venoocclusive disease. Am J Pathol 1966; 48: 597-611.

28. Garin E, Rolland Y, Edeline J. 90Y-loaded microsphere SIRT of HCC patients with portal vein thrombosis: High clinical impact of 99mTc-MAA SPECT/CTbased dosimetry. Semin Nucl Med 2019; 49: 218-26.

29. Sangro B, Gil-Alzugaray B, Rodriguez J, Sola I, Martinez-Cuesta A, Viudez A, et al. Liver disease induced by radioembolization of liver tumors: description and possible risk factors. Cancer 2008; 112: 1538-46.

30. Lewandowski RJ, Memon K, Mulcahy MF, Hickey R, Marshall K, Williams M, et al. Twelve-year experience of radioembolization for colorectal hepatic metastases in 214 patients: survival by era and chemotherapy. Eur J Nucl Med Mol Imaging 2014; 41: 1861-9. 